JELTL (Journal of English Language Teaching and Linguistics) e-ISSN: 2502-6062, p-ISSN: 2503-1848

2018, Vol. 3 (1)

www.jeltl.org

\title{
Being an E-Teacher: Preparing the ESL Teacher to Teach English with Technology
}

\author{
Ismail Anas \\ State Polytechnic of Ujung Pandang \\ ismailanas@poliupg.ac.id \\ Andi Musdariah \\ State Polytechnic of Ujung Pandang \\ Musdariahandi.am@gmail.com
}

\begin{abstract}
In response to the extensive use of technology in the field of education particularly in English language teaching (ELT) context, both the pre-service and in-service ESL teachers are expected to use ICT tools in their teaching and learning environment. It is important to have a closer look at the use of ICT tools and the ease of access to the internet to see the opportunities to harness the technology resources for effective blended learning. Recently, although many studies revealed merely to promote the student's self-directed learning and the successful of CALL, it is the teacher as a key role to blend such technologies into an effective teaching strategy. This study strives to develop a conceptual framework for teaching English with technology. The framework delineates six perennial aspects of e-teacher development; they are; (1) teacher technology competency, (2) professional use of ICT tools, (3) professional use of the Internet, (4) web-based technology skills, (5) ESL teacher's digital literacy, and (6) ESL materials and resources development. This concept will bring many contributions to the way ESL teacher exploit the technology resources for an adaptive and interactive teaching strategy. This paper also provides the implications for the practice, teacher, and student.
\end{abstract}

Keywords: E-Teacher, conceptual framework, ICT, ESL teacher, and ELT 


\section{INTRODUCTION}

Preparing the pre-service and in-service ESL teacher to teach English with technology requires several prerequisites that enable them to exploit the technology resources for effective and efficient ELT. The use of ICT in language education becomes more prominent as an impact of the rapid changing of educational technology in the field of language teaching. The importance of technology integration in a blended learning environment and how to teach English with technology attracts CALL researchers to do an in-depth investigation in this area (Bradley, 2013; Dudeney \& Hockly, 2007; Jia, 2015; Szecsy, 2015). Dealing with technology becomes a daunting task for most teachers who are not technologically literate. Teachers must be well-trained and familiar with the high-end technologies to integrate the ICT tools and the pedagogical aspects of teaching (e.g. Rozgiene, I. Medvedeva, O. Strakova, 2008). Most ESL teachers lack necessary competence to work on such integration and could not move beyond their comfort zone. Based on the traditional teaching perspective, the learning activity is more teacher-centered stressing on the teacher-dominated interaction (Boumová, 2008).

The technology keeps changing very rapidly so that the language educators will need to advance and improve their technological skills to adapt with the latest updates ICTs. Therefore, the ICT competencies of EFL teachers should be improved (see Malinina, 2015). The adaptation to the technology updates takes a longer period and is not an instant process. Starting from the earliest 1990's or even later in the millennium, the pre-service teacher education in Indonesia put a little attention to the importance of technological skills that hindered the language educator from the actual use of ICTs. The teaching industries relied on the teaching-based institutes to fulfill the enormous demand for professional teachers in many disciplines. This condition had an impact on the current education where the existing senior teachers still lack functional technology in instruction. The percentage of senior teachers is still large in numbers so that the teacher regeneration should become the primary focus in any levels of pre-service teacher education.

Teaching English with Technology is still a complex issue among the ESL teachers in Indonesia. For instance, inadequate ICT facilities, troubleshooting support, difficulties in finding appropriate video, video editing skills, and student participation in learning are the factors affecting the use of ICTs in the classroom (Nova, 2017). ESL teacher and language educators need a standard and a framework for incorporating ICTs into the teaching and learning horizon. The lack of technology-focused training for the in-service teachers is one of the factors affecting the uptake of ICTs in education. In recent years, both the local and national authorities for educational service including the non-government organizations (NGOs) have been working intensively in conducting training on the use of ICTs in teaching and learning context. Notwithstanding the myriad of available resources and training in a wide-range of education sectors, it is also important to investigate the teacher attitude towards the technology (Yusuf \& Balogun, 2011). In fact, many teachers become reluctant to participate in such training. Moreover, their participation depends on the amount of credit point they can earn. Most of the training are in a short course format which offers no credit point affecting the 
teacher's decision making to join the event. This intrinsic motivation kills the teacher's potentials in developing the insights of professional teaching and expertise. In the other hand, innovation of technology in language teaching and learning has become a prerequisite element in providing a quality teaching for the students (Mansor, Halim, \& Rahim, 2017).

\section{THE E-TEACHER DEVELOPMENT}

This section outlines the importance of e-teacher development as a response the sophisticated educational technologies in the 21 st century. Being an e-teacher in the digital world requires the existing ESL teachers in all level of education to teach English using internet and technology. Both the internet and technology literacy supports the e-teacher development program that allows the teachers to get engaged and involved in an online learning space. The internet skills help the teacher to access information in the world educational databases. The information is then processed by the teacher's critical thinking and pedagogical knowledge to make a right mix of strategies using ICT tools. In the later section of this article, there will be a vivid elaboration of each aspect of the framework on how to be an e-teacher (see figure 1). In addition, the provision of the e-teacher program will provide a wide access to an inclusive education around the world particularly e-education for the language learners with disabilities (Bjekić, Obradović, Vučetić, \& Bojović, 2014)

The role of e-teacher is to facilitate learning using different types of competencies such as pedagogical knowledge, technical skills (technological skills), communication and interpersonal skills. Denis and his co-authors (2004) and later re-emphasized in Bjekic et.al (2010) classify the e-tutor roles into two major points as follows:

Table 1: The roles of e-tutor in an online teaching and learning

\begin{tabular}{|c|c|c|c|}
\hline \multicolumn{2}{|c|}{ Central characters (T-S Interaction) } & \multicolumn{2}{|r|}{ Peripheral role } \\
\hline E-tutor roles & Activities and behaviors & E-tutor roles & Activities and behaviors \\
\hline $\begin{array}{l}\text { Content } \\
\text { Facilitator }\end{array}$ & $\begin{array}{l}\text { Sometimes intervenes as a } \\
\text { subject expert, sometimes as } \\
\text { interpreter and guide through the } \\
\text { concepts of study }\end{array}$ & $\begin{array}{l}\text { Manager/ } \\
\text { administrator }\end{array}$ & $\begin{array}{l}\text { the e-tutor supports the } \\
\text { management of the course } \\
\text { keeping records, checking the } \\
\text { enrollments }\end{array}$ \\
\hline $\begin{array}{l}\text { Metacognition } \\
\text { facilitator }\end{array}$ & $\begin{array}{l}\text { he/she supports reflection on } \\
\text { learning activities and outcomes, } \\
\text { study skills development }\end{array}$ & Designer & $\begin{array}{l}\text { he/she can sometimes } \\
\text { intervene to help to design the } \\
\text { course or course module, the } \\
\text { 'lesson' itself - the } \\
\text { pedagogies, the tasks to be } \\
\text { done }\end{array}$ \\
\hline $\begin{array}{l}\text { Process } \\
\text { facilitator }\end{array}$ & 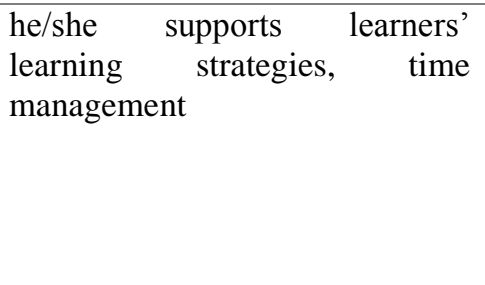 & Co-learner & $\begin{array}{l}\text { often, the role of the e-tutor is } \\
\text { not 'stage on the stage' or even } \\
\text { 'guide on the side', but } \\
\text { genuinely 'friend to the end' of } \\
\text { the course, walking with the } \\
\text { learner- participants and } \\
\text { learning alongside them }\end{array}$ \\
\hline $\begin{array}{l}\text { Advisor } \\
\text { (counselor) }\end{array}$ & $\begin{array}{l}\text { he/she provides pastoral support, } \\
\text { the doorway to institutional/local } \\
\text { support systems }\end{array}$ & Researcher & $\begin{array}{l}\text { he/she can be a reflective } \\
\text { practitioner and action } \\
\text { researcher from his/her e-tutor }\end{array}$ \\
\hline
\end{tabular}




\begin{tabular}{ll}
\hline \begin{tabular}{l} 
Assessor \\
(formative \& $\begin{array}{l}\text { he/she gives feedback on task } \\
\text { summative) } \\
\text { achievement and performance, } \\
\text { assignment development, } \\
\text { sometimes he/she is also an } \\
\text { examiner }\end{array}$ \\
\hline Technologist
\end{tabular} $\begin{array}{l}\text { he/she is a guide, first-post } \\
\text { support with technologies and } \\
\text { tools for learning }\end{array}$ \\
\hline $\begin{array}{l}\text { Resource } \\
\text { provider }\end{array}$ & $\begin{array}{l}\text { He/she identifies and locates, } \\
\text { develops and produces resources } \\
\text { to provide 'just in case' or 'just } \\
\text { in time' learning support. }\end{array}$ \\
\hline
\end{tabular}

Teacher as a content facilitator is responsible for the concept of the study which provides the fundamental meaning of the subject. In the context of online teaching and learning, the teacher facilitates learning through a platform (e.g. Moodle-based e-learning, facebook learning, Dokeos, MOOCs, Chamilo, and other web-based technologies) that supports collaborative activities among the students. Besides that, the teacher can also provide digital resources for the students such as an e-book, digital images, videos, sounds, and podcasts, alternatively, providing external web links to online resources is also useful. Secondly, teacher functions as a metacognition facilitator that helps the learners draw a conclusion and give feedback to what the students have worked out. The reflection may be either at the beginning or the end of the lesson reflecting the previous discussion. Thirdly, the teacher plays a pivotal role as a facilitator process in learning that support learner's learning strategy and time management. In this point, teacher functions as a guide to help the student reach the learning goals and objectives. Fourthly, the teacher should bear in mind that his role as a counselor will assist the student to communicate with teacher whenever the student faces a problem in the process of learning. In short, the teacher should provide counseling as a mentor or a problem solver for the student. Fifthly, the teacher makes an evaluation of the student progress by doing an assessment in a variety of methods such pre-evaluation, whilst-evaluation, and post-evaluation. The evaluation is necessary to get a clear picture of the student's understanding and comprehension. Sixthly, teacher as a technologist will have a crucial role in selecting the appropriate ICT tools for learning. It strongly relates to the student's acceptance of technology meaning that either the student can use such technology or the technology has a positive impact on the student's cognition. The last issue of the central role is a teacher as resource provider whose job is to help the student obtain information from a variety of sources such as off-print materials and digital resources. The off-print materials are a book, printed article, worksheet, magazine, newspaper, report, thesis, etc., and digital resources are a web page, online dictionary, digital image, video, podcast, online library, articles in electronic journals, etc. About the e-teacher development, the teacher plays a crucial role as a learning agent as well as a technologist to bridge these function into a technologyassisted teaching and learning environment. 
Some e-teacher development programs offer a comprehensive and interactive online course for teachers and educational practitioners across the nations. The availability of online courses provides a new horizon in facing the digital learning environment. Recently, the massive open online course (MOOCs) has attracted more teachers to participate in such e-teacher program training. Self efficacy, teaching precence, and perceived usefulness should be noticed as influential factors affecting the learning engagement (Jung \& Lee, 2018).Notwithstanding the multi-facets problems of teachers in online education programs, the rise of MOOCs has become more attractive to the teachers worldwide in disseminating knowledge and experience. Given the importance of MOOCs in online education programs, the teacher will have to understand the main properties of the platform to be able to participate and engage in such online course. This gap encourages the academic scientists to work on this project and has attracted them to contribute to this field. The nature of MOOCs suggests a fascinating and engaging insight of learning beyond the boundaries. For further reading on this issue, it is now available on books, journal articles, generic, report, and other sources of information including web pages (e.g. Hayes, 2015; Voss, 2013).

\section{THE ESL E-TEACHER FRAMEWORK}

In support to prepare both the pre-service and in-service ESL teachers to teach with technology, this study strives to delineate a conceptual framework to guide language educators to use technology in delivering content materials. This concept is hoped to contribute to the teacher preparation programs regarding teaching English with technology. Six perennial aspects are contributing to the professional insights of being an e-teacher for language teaching. They are; (1) teacher technology competency, (2) professional use of ICT tools, (3) professional use of the Internet, (4) web-based technology skills, (5) ESL teacher's digital literacy, and (6) ESL materials and resources development. This initial concept delineates three primary cycles of development; they are; (1) teacher education and training, (2) the integration of technology, and (3) the pedagogical consideration (see figure 1).

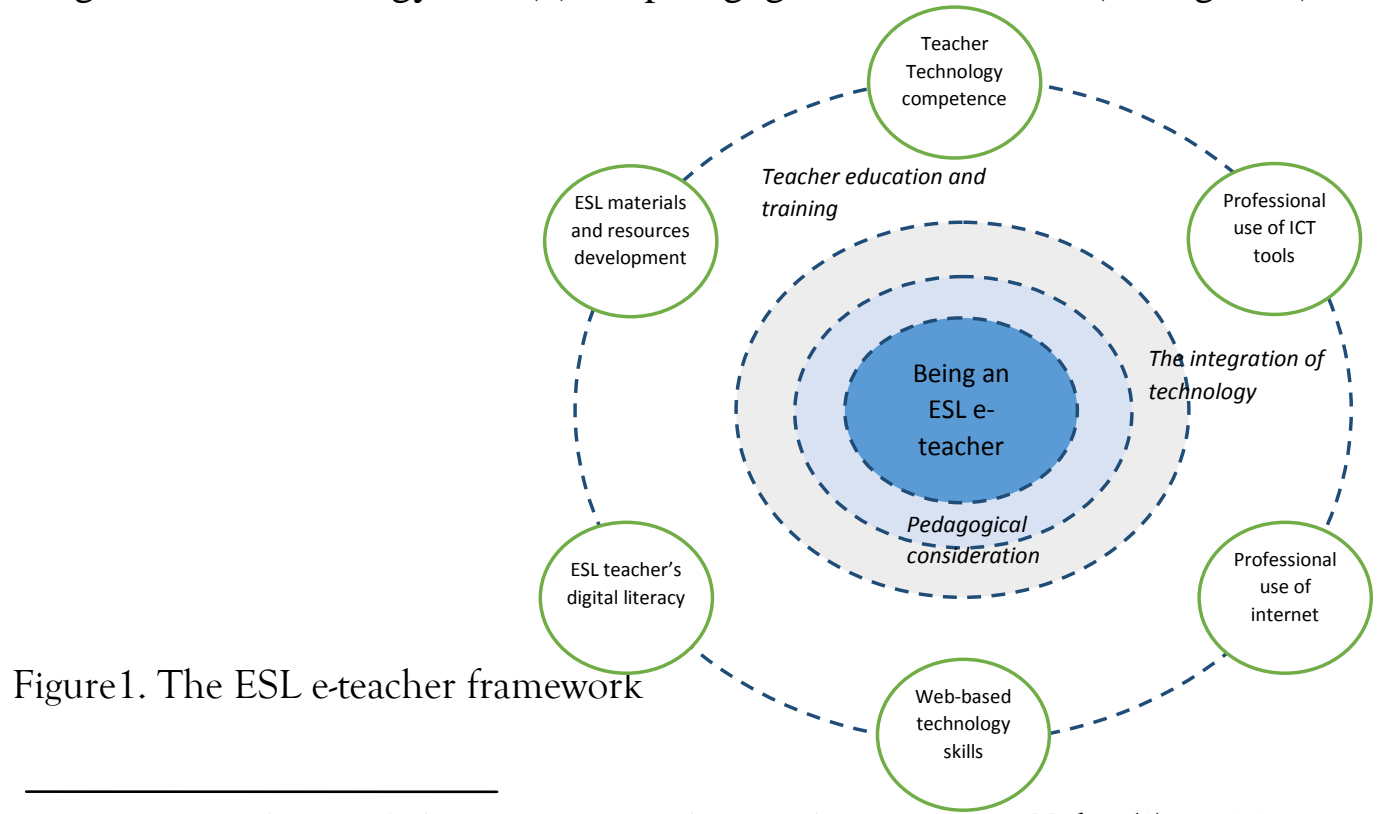


Figure 1 illustrates the initial conceptual framework of being a professional eteacher that proposes a guide for ESL teachers to exploit and blend the technology for use in English language teaching. In general, this concept may also work in other disciplines within the core of education. Firstly, the outer cycle focuses on the fundamental aspects of e-teacher development that put an emphasis on the six perennial issues as initial prerequisites for pre-service and in-service ESL teachers. This first phase suggests infusing these matters into pre-service and in-service teacher training programs before entering the next step of technology integration. The e-teacher development can be orchestrated through teacher education programs or a self-study with an autodidact approach.

The second cycle focuses on the integration of technology to produce a right mix of teaching a particular topic. The ability to blend such technology depends on the teacher competency to harness the technology resources and materials that meet the student needs and expectation. The teacher has authority to select the appropriate ICT tools and pick the materials for constructing a right blend that shapes knowledge and potentially promotes the student's cognition. The third cycle focuses on a pedagogical consideration which determines the methodological aspect of teaching. It is important to ensure that the blend of technology integration can promote the student's cognition and shape knowledge. We cannot just use technology as a mediated learning without considering the aspect of the student's understanding and comprehension. The teacher should use their critical thinking to pick and design a right teaching strategy to achieve the specific goals and objectives. The teacher TPACK framework has outlined the importance of pedagogical knowledge as an influential aspect in selecting the best teaching strategy to deliver content materials (e.g. Koehler, Mishra, Akcaoglu, \& Rosenberg, 2013; Mishra \& Koehler, 2008). In this digital world, teachers are expected to able to demonstrate their ability to utilize technology and develop useful content materials.

\section{THE ISSUE ON THE TEACHER TECHNOLOGY COMPETENCY}

Are the teachers technologically competent? This question addresses the readiness of the teacher to deal with technology and its application in teaching and learning environment. This issue has been investigated in the United States of America in the late 1990s. The teacher technology competency committee in association with American universities has set up the technology competency standard for teachers. The technology competencies framework focuses on four domains; they are; (1) basic technology operation, (2) personal and professional use of technology tools, (3) social, ethical, and human issues, (4) application of technology in instruction (Teacher Technology Competency Committee, 1998). The basic technology operation set by the TTC should be further adjusted to the current development of technology due to the fast changing of innovations from time to time. The importance of the technology competencies has attracted the world organization (UNESCO) to take part in developing teacher technology skills as an integral part of today's teaching context (Unesco, 2008, 2011).

In today's English teaching, there is a high demand of technologically knowledgeable ESL teacher to promote the e-teaching engagement among schools 
and higher educations. In this globalized area, the growth of information technology has enabled the ESL teacher to create innovations as a means of knowledge transferring. If the teacher is not technologically knowledgeable, he/she will not be able to integrate the ICTs in teaching and learning that shapes the student's cognition. This argument would be a strong emphasis on the teacher technology repertoire. It then enables ESL teachers to process the information to choose appropriate ICT tools and pedagogical strategies to reach the learning goals and objectives. Zhang et.al (2014) states that "from curriculum mandates of ICT to pedagogical use or non-use of ICT, various factors intrinsic and extrinsic to teachers came into play." He also stressed the use of ICTs as a means of pedagogical teaching tools to make an effective content materials delivery. The teachers can use their critical thinking to prepare the teaching and educational resources that meet the student needs and expectations. In the process of technology integration, the academic scientists have been working in this area along with the rapid development of technology. The teacher will need a guideline for integrating technology inside and outside the classroom. There are six integral domains of teacher training processes in technology integration in which each area is associated with a set of teaching generic competencies (e.g. Guzman \& Nussbaum, 2009).

Empowering ESL teachers to engage with technology is not an instant process. It is necessary to re-train and equip them with technological skills within an intensified training program. The in-service ESL teachers who have much teaching hours should consider saving time to attend such training program. A school principal or a director of higher education will have to encourage them to participate rigorously in such skill training program. In some case studies, the teacher engagement in ICT training programs still becomes a crucial issue to investigate (Khan \& Hasan, 2013; Rienties, Brouwer, \& Lygo-Baker, 2013).

\section{ICT TOOLS AND THE LEADING-EDGE APPLICATIONS FOR ELT}

The availability and affordability of ICT tools in the current educational environment brings a new wave of English language teaching (Ghasemi \& Hashemi, 2011). It allows ESL teacher to integrate and incorporate technology into a learning setting using a set of tools for knowledge transferring. The leading-edge of applications for use in an educational environment is now available in almost schools and higher educations in an urban area. A student can now have an easy access to use the facilities such as computer lab with LAN connection, multimedia lab, LCD projector, interactive whiteboard, language lab, and learning software. These tools allow the teacher to create a collaborative learning environment inside and outside the classroom. About the ICT integration, Rozgiene et.al (2008) developed a comprehensive ICT integration guide for teacher focusing on how to implement technology-enhanced teaching. They also put an emphasis on the pedagogical and psychological aspects of technologically-enhanced learning.

In ELT context, the ESL teacher will need to do further investigation of technology integration for language learning. A small talk with a language laboratory coordinator revealed a gap in the teacher's attitude towards the language lab facilities and its application in learning activities (Ahmad, 2015). He then 
compared with the previous early language learning services that the teacher preferred to using the analog system rather than the latest updates with digital technology system. We cannot judge the old one is better than the new one; it is about a matter of the teacher technology competency to accept the new updates on ICT tools. He then continued talking his worries about the future prospect of its utilization as a useful learning tool. Regarding the system familiarity, it needs longer period and rigorous effort to equip the existing ESL teachers to be willing to learn new technology in which, of course, they are not familiar with it. This hearing tells us that the fast changing technology requires, indeed, a quick learner.

All we need is the inclusive learning approaches for literacy, language, numeracy and ICT. This, at least, will help the ESL teacher identify the learner's needs such as personal, social, and cultural factors (Sector \& Council, 2007). The ability to accept technology will enable the ESL teachers to encounter any changes and the latest updates on the technology. With ICT skills, they can make the decision to select appropriate ICT tools and to find possible applications for an efficient teaching strategy. It is also necessary to intensify the development programs such as training and workshop concerning the technology utilization in language teaching.

\section{THE EASE OF ACCESS TO THE INTERNET AND ITS POTENTIAL USE IN A BLENDED LEARNING ENVIRONMENT}

The Internet is the potential language learning tool (Evans, 2009). Teachers who have a good access to the internet will make them easier to search useful information and online resources for use in language teaching. There is a changing behavior of the student in doing their tasks in which they mostly rely on the internet for searching information as the complementary sources to support their work. They can easily trace articles within the corpus-based information from many databases around the world. The latest development in an online storage system is the cloud computing technology that allows the user to upload and download information such as files, dataset, multimedia-based content, and many others. This phenomenon will have either an adverse impact on the student's critical thinking to filter the information or to promote their ability in processing the information.

The potential use of the internet in a blended learning environment is pervasive. The Internet-Based Language Learning And Teaching (IBLLT) becomes more familiar and widely-used in the practice of ELT (Agarwal, 2010). The internet can support the inclusive digital society by connecting more people to an online interaction through a social media platform. With the internet, the teacher can search for useful online resources for use in their teaching. In this point, the importance of the internet literacy is stressed. The ESL teacher as a digital citizen should have, at least, a thorough internet literacy to explore the potentials of this tool for use in language teaching and learning.

In ELT, the internet supports the ESL teacher to open access to digital resources that may contribute to their work. We might find some benefit of the internet as:

1. language learning tool 
2. language research tool

3. an online collaboration of ESL teachers

4. a means of communication 2.0 among the ESL teachers

5. a cloud of the corpus linguistics

\section{THE RISE OF WEB-BASED TECHNOLOGY}

The rise of web-based technology such as web 2.0, e-learning platforms, blogs, and social networking sites offers a new nuance of online teaching and learning interaction. The number of users of web-based technologies is now growing very rapidly especially the social networking sites (e.g. Facebook and Twitter). This situation also brings changes to the way people communicate with friends and colleagues where they build virtual communication channels- as it is called 'communication 2.0.' This type of communication becomes more familiar with the digital citizens in which they can make fast communication and stay connected with the communities. In the context of online ELT, this allows the ESL teachers to reach their students beyond the time and place boundaries. The review of web-based technologies in education might be useful for ESL teachers who want to start using them in their teaching activities (e.g. F.O'Neil, 2013; Hylton, 2011; Lyashenko, 2016; Pajo \& Wallace, 2007)

A myriad of online tools for language teaching has attracted the CALL researchers and ELT practitioners to explore their utilization and use into practice. Son.J.B (2011) outlined the categories of online web-based technologies for language teaching as follows:

Table 2 The categories and web-based technologies/tools for language teaching

\begin{tabular}{|c|c|c|}
\hline No & Categories & Web-based Technologies/Tools \\
\hline 1 & LMSs/CMSs & $\begin{array}{l}\text { Blackboard, Drupal, Joomla, Moodle, Chamilo, Dokeos, and } \\
\text { Sakai. }\end{array}$ \\
\hline 2 & Communication & $\begin{array}{l}\text { Gmail, Skype, TokBox, Windows Live Messenger, Yahoo! } \\
\text { Messenger, Jabberwacky, Verbot, MyBB, phpBB, Tangler and } \\
\text { Voxopop }\end{array}$ \\
\hline 3 & Live and virtual worlds & $\begin{array}{l}\text { Elluminate, Livestream, OpenSimulator, ActiveWorlds, Second } \\
\text { Life, Ustream, Wimba Classroom and WiZiQ }\end{array}$ \\
\hline 4 & $\begin{array}{l}\text { Social networking and } \\
\text { bookmarking }\end{array}$ & $\begin{array}{l}\text { Delicious, Diigo, Elgg, Facebook, Grouply, MySpace, Ning, } \\
\text { SocialGo, LinkedIn, Twitter, Lang- } 8 \text { and Livemocha }\end{array}$ \\
\hline 5 & Blogs and wikis & $\begin{array}{l}\text { Blogger, Edmodo, Edublogs, LiveJournal, WordPress.com, } \\
\text { PBWorks, Wikispaces and Penzu }\end{array}$ \\
\hline 6 & Presentation & 280 Slides, Animoto, Empresser, Prezi, SlideRocket and Zoho \\
\hline 7 & Resource sharing & $\begin{array}{l}\text { Google Docs, TitanPad, Zoho Writer, Box.net, Dropbox, } \\
\text { VoiceThread, Xtranormal, Flickr, Picasa, MyPodcast, } \\
\text { PodOmatic, Glogster, Screen, Slideshare, PhotoPeach, Dipity, } \\
\text { OurStory, Jing, SchoolTube, TeacherTube, VideoPress, Vimeo, } \\
\text { WatchKnow and YouTube }\end{array}$ \\
\hline 8 & Website creation & $\begin{array}{l}\text { Google Sites, Jimdo, KompoZer, Mahara, Movable Type, } \\
\text { SnapPages, Weebly, Webnode, Webs and Wix }\end{array}$ \\
\hline 9 & Web exercise creation & $\begin{array}{l}\text { ContentGenerator, SMILE, ESL Video, JClic, Hot Potatoes, } \\
\text { Quia, Lingt and Listen and Write }\end{array}$ \\
\hline 10 & Web search engines & Ask.com, Bing, Google, and Yahoo! Search \\
\hline 11 & Dictionaries & Merriam-Webster \\
\hline
\end{tabular}




\begin{tabular}{lll}
\hline concordancers & $\begin{array}{l}\text { YourDictionary.com, Compleat Lexical Tutor, Forvo, Howjsay, } \\
\text { Visuwords, OneLook Dictionary Search and VLC Web } \\
\\
\text { Concordancer }\end{array}$ \\
\hline $\mathbf{1 2}$ Utilities & CalculateMe, CalendarFly, Doodle, ClustrMaps, Currency \\
& Converter, Dvolver Moviemaker, Google Earth, Lesson Writer, \\
& Storybird, Cacoo, MindMeister, Mindomo, Remember the milk, \\
& SurveyMonkey, Voki, Time and Date, TinyURL.com, W3C \\
& Link Checker, Wallwisher, Wayback Machine and Wordle
\end{tabular}

Table 2 outlines twelve categories of web-based technologies/tools that the ESL teachers can utilize them as a medium of online teaching. It is important that the ESL teacher has, at least, technological literacy to be able to work on such tools. They can select the appropriate tools that help them in the process of content material delivery. It is also important to notice that they do not have to master the above tools, but they should be able to use, at least, one in each category. With a proper technological literacy, the ESL teacher will be able to welcome new updates on technology without needing to take a longer time to study and re-study them.

\section{ARE YOU DIGITALLY LITERATE?}

Digital literacy is not only all about the ability to read and write anymore, but it also covers the capacity to process the information in multiple formats from a broad range of sources when it is presented via computer (Gilster, 1998). In recent years, it is redefined as a more complexed literacy along with the advances in technology and its use in the educational sector. Teachers today demanded to be able to use ICT tools as an integral part of modern learning. In this digitalized era, the ESL teachers should be digitally literate. It is necessary the ESL teacher understand the digital literacy (e.g. Boechler, Dragon, \& Wasniewski, 2014), digital literacy and digital literacies (e.g. Lankshear \& Knobel, 2006), and digital literacy in language teaching and learning (e.g. Dudeney, Hockly, \& Pegrum, 2014). He and his coauthor also developed a framework of digital literacy as follows:

Table 3: Framework of Digital Literacy (Dudeney et al., 2014. p.17)

\begin{tabular}{|c|c|c|c|c|}
\hline \multirow{10}{*}{ 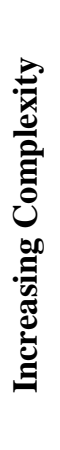 } & $\begin{array}{c}\text { First Focus: } \\
\text { Language }\end{array}$ & $\begin{array}{l}\text { Second Focus: } \\
\text { Information }\end{array}$ & $\begin{array}{l}\text { Third Focus: } \\
\text { Connections }\end{array}$ & $\begin{array}{c}\text { Fourth Focus: } \\
\text { (Re)-Design }\end{array}$ \\
\hline & Print Literacy & & & \\
\hline & Texting Literacy & & & \\
\hline & Hypertext Literacy & Tagging Literacy & & \\
\hline & & Search Literacy & Personal Literacy & \\
\hline & Multimedia Literacy & Information Literacy & Network Literacy & \\
\hline & & Filtering Literacy & Participatory Literacy & \\
\hline & Gaming Literacy & & Intercultural Literacy & \\
\hline & Mobile Literacy & & & \\
\hline & Code Literacy & & & Remix literacy \\
\hline
\end{tabular}


Table 3 outlines the framework of digital literacy focusing on four domains; they are:

1. Language literacy: he put the print literacy as the less complexed literacy and code literacy as the most complexed literacy.

2. Information literacy: he set the filtering literacy as the most complexed among the four others meaning that a teacher should have the ability to filter the information they found on the internet.

3. Connections Literacy: the ability to build relationships with other people in the virtual world. For instance, network literacy allows an individual to create and maintain systems as a means of staying connected with other online users.

4. Remix literacy: it is the ability of an individual to mix literacies for use in an online teaching and learning.

In this section, I would like to bring an emphasis on the importance of digital literacy as a skill needed to face the digitalization in language learning. The digital literacy skill empowers teachers to deliver content materials in various ways. A teacher who usually use Microsoft power point in his/her presentation may give a try using other presentation tools such as Animoto, Prezi, Slide Rocket, and Soho (see Table 2). It will help the teacher create a new nuance in material delivery that probably interest the students. Another case related to the digital literacy skill is the use of video conferencing tools in online communication using a live chat. The digital literacy skill has a significant role in helping the teacher understand the software such as the use of it, how it works, and how to troubleshoot the problems encountered during its application. Embracing digital literacy in today's teaching and learning is necessary for that it helps the teacher to stay updated with the current advances in educational technology.

In this digital era, we might see around us the fast changing of student's behavior in learning. They might be boring reading a printed version of books, working on the same worksheet, discussing the same topic, and experiencing a flat learning environment. They mostly possess their tablets, smartphones, laptops, and other hand-held devices that a teacher should see it as an opportunity to explore a possible technological-based learning. In fact, the students of today are more advanced in technology that the teachers are, so they might not have a choice but to develop their technological skills. In the other hand, some teachers or professors are non digital native so they might be difficult to adapt with the new technologies due to age matter (Laabidi, 2016). They might need more time to be able to utilize a spesific ICT tools for their teaching.

\section{ESL MATERIALS AND RESOURCES FOR A BLENDED LEARNING ENVIRONMENT}

Given the importance of successful teaching and learning, materials and resources are pivotal elements as perennial factors in education. In a traditional classroom, learners tend to be monotonous in which they only learn from limited sources. The materials such as books, papers, and worksheets are less attractive and outdated. Materials and resources need further development to meet the student 
needs and expectation. About material development, the teacher will need more resources to diversify the learning contents. The teacher ability in developing material is a crucial factor to succeed the process of teaching and learning. Tomlinson, B (2011) in his edited book outlined the concept of materials development in language teaching. He argued five important points in materials development; they are:

1) The ESL teacher should be able to clarify the terms and concepts in materials development,

2) The ESL teacher should be able to carry out evaluation of the current materials that to what extent the materials facilitate language learning,

3) The ESL teacher should be able to consider the potential applications for materials development of current research into SLA and language use,

4) Both the ESL teacher and student should be able to find the possible applications in which they can use in language learning, and

5) The language material developers should pool potential resources and bring together researchers, writers, teachers, learners and publishers as an endeavor for quality materials.

The ESL teacher should be able to search, filter, and develop online materials and resources for use in a blended learning environment. A right blend of materials and technologies will enable ESL teacher to create an effective teaching strategy. Further reading about teaching English with technology and its innovation in language teaching and learning, the language teaching experts has written useful strategies and innovative ideas for English language teaching (Dudeney \& Hockly, 2007; Motteram, 2013; Pickering \& Gunashekar, 2015)

\section{CONCLUSION}

The availability and affordability of ICT tools for language teaching, it becomes a daunting task for most ESL teacher. The teachers' technophobia hampered them from the actual use of technology and its integration in language teaching and learning. A look at this issue is simply necessary to take into account to encounter the teacher's reluctance in utilizing technology as a medium of instruction. This article provides a guideline and framework on how to be an eteacher in a language teaching environment. The focus of this paper emphasizes on six domains of being a technologically-literate ESL teacher. Firstly, the ESL teachers should develop their technological competencies and skills to be able to use ICT tools in language teaching and learning. They should know, at least, the basic technology operation to further work on CALL environment. Secondly, if they have already obtained such basic technological skills, they will need to develop their skills to use the ICT tools professionally. Thirdly, the knowledge and skill of technology should be supported by the internet literacy to explore further the available online resources. Fourthly, the ESL teacher should develop from the internet literacy to web-based technology skills because working with the internet cannot be separated from web-based applications. Fifthly, being engaged with the internet and web-based technology, the ESL teacher will need a digital literacy skill. The digital literacy skills will enable them to encounter and troubleshoot the 
problems occurred during the process of learning. The last is materials and resources development in which the ESL teachers are expected to be able to develop the materials by making innovation and planning an effective strategy for ELT. The integration of technology in ELT should pay attention to the pedagogical consideration as a foundation of knowledge transferring. At last, technology is simply a tool that helps us work easier and efficient.

\section{REFERENCES}

Agarwal, M. K. (2010). Internet-Based Language Learning and Teaching. Innovative Infotechnologies for Science, Business, and Education, 1(8), 3-7. https://doi.org/10.1017/S0272263104293056

Ahmad. (2015). The utilization of language lab facilities in ELT. A hearing from the Language Laboratory Coordinator of PNUP.

Bjekić, D., Krneta, R., \& Milošević, D. (2010). Teacher education from e-learner to E-teacher: Master curriculum. Turkish Online Journal of Educational Technology, 9(1), 202-212.

Bjekić, D., Obradović, S., Vučetić, M., \& Bojović, M. (2014). E-teacher in inclusive e-education for students with specific learning disabilities. Procedia - Social and Behavioral Sciences, 128, 128-133. https://doi.org/10.1016/j.sbspro.2014.03.131

Boechler, P., Dragon, K., \& Wasniewski, E. (2014). Digital Literacy Concepts and Definitions:Implications for Educational Assessment and Practice Patricia. International Journal of Digital Literacy and Digital Competence, 5(4), 1-18. https://doi.org/10.4018/ijdldc.2014100101

Boumová, V. (2008). Traditional vs . Modern Teaching Methods : Advantages and Disadvantages of Each. Masaryk University. Retrieved from https://is.muni.cz/th/86952/ff_m_b1/MgrDiplomkaBoumova.pdf

Bradley, L. (2013). Language, Learning and Technology. University of Gothenburg. Retrieved from http://hdl.handle.net/2077/32322

Denis, B., Watland, P., Pirotte, S., \& Verday, N. (2004). Roles and Competencies of the e-Tutor. In Networked Learning Conference (pp. 1-8). Retrieved from http://www.networkedlearningconference.org.uk/past/nlc2004/proceedings/sym posia/symposium6/denis_et_al.htm

Dudeney, G., \& Hockly, N. (2007). How to Teach English with Technology. Computer Assisted Language Learning. https://doi.org/10.1093/elt/ccn045

Dudeney, G., Hockly, N., \& Pegrum, M. (2014). Digital literacies: Research and resources in language teaching. Routledge.

Evans, M. J. (2009). Foreign language learning with digital technology. London SE1 7NX: Continuum International Publishing Group. Retrieved from $\mathrm{http} / / /$ books.google.com/books?id=c_WbnOJlHHsC\&pgis $=1$

F.O'Neil, H. . \& R. S. P. (2013). Web-Based Learning: Theory, Research, and Practice. London: Lawrence Erlbaum Associate. Retrieved from http://books.google.com/books?hl=id\&lr=\&id=JW4nAAAAQBAJ\&pgis=1

Ghasemi, B., \& Hashemi, M. (2011). ICT: Newwave in English language learning/teaching. In Procedia - Social and Behavioral Sciences (Vol. 15, pp. 
3098-3102). Elsevier Ltd. https://doi.org/10.1016/j.sbspro.2011.04.252

Gilster, P. (1998). Digital Literacy. Wiley Computer Publishing. New York: Waley.

Guzman, A., \& Nussbaum, M. (2009). Teaching competencies for technology integration in the classroom. Journal of Computer Assisted Learning, 25, 453469. https://doi.org/10.1111/j.1365-2729.2009.00322.x

Hayes, S. (2015). MOOCs and Quality: A Review of the Recent Literature QAA MOOCs Network. QAA MOOCs Network.

Hylton, S. (2011). Web based technology. Retrieved March 14, 2015, from http://www.slideshare.net/Shallon_Hylton/web-base-technology-12997631

Jia, J. (2015). Information and Communication Technology and Language Education. In Intelligent Web-Based English Instruction in Middle Schools (pp. 1-28). https://doi.org/10.4018/978-1-4666-6607-8.ch001

Jung, Y., \& Lee, J. (2018). Learning engagement and persistence in massive open online courses (MOOCS). Computers \& Education. https://doi.org/10.1016/j.compedu.2018.02.013

Khan, S., \& Hasan, M. (2013). Introducing ICT into Teacher-Training Programs: Problems in Bangladesh. Journal of Education and Practice, 4(14), 79-87.

Koehler, M. J., Mishra, P., Akcaoglu, M., \& Rosenberg, J. M. (2013). The technological pedagogical content knowledge framework for teachers and teacher educators. ICT iItegrated Teacher Education: A Resource Book.

Laabidi, H. (2016). The effect of age on English professors' integration of the new technologies in teaching. Indonesian Journal of English Language Teaching and Applied Linguistics, 1(1), 63-74.

Lankshear, C., \& Knobel, M. (2006). Digital literacy and digital literacies. Nordic Journal of Digital Literacy, 12-24. Retrieved from http://www.everydayliteracies.net/files/digital_kompetence_2006.pdf

Lyashenko, M. S. (2016). Implementation of Web-Based Technologies into Teaching and Learning Practices in the University. International Journal of Information and Education Technology, 6(3), 243-246. https://doi.org/10.7763/IJIET.2016.V6.693

Malinina, I. (2015). ICT Competencies of Foreign Languages Teachers. Procedia Social and Behavioral Sciences, 182, 75-80. https://doi.org/10.1016/j.sbspro.2015.04.740

Mansor, N. S., Halim, H. A., \& Rahim, N. A. (2017). Students ' perspectives towards innovation of technology in teaching and learning of language. Indonesian Journal of EFL and Linguistics, 2(2), 121-132.

Mishra, P., \& Koehler, M. J. (2008). Introducing technological pedagogical content knowledge.

Retrieved

from http://punya.educ.msu.edu/presentations/AERA2008/MishraKoehler_AERA20 08.pdf

Motteram, G. (2013). Innovations in learning technologies for english language teaching. London SW 1A 2BN,UK: British Council.

Nova, M. (2017). Utilizing video for technology integration support in Indonesian EFL classroom: usages and obstacles. Indonesian Journal of EFL and Linguistics, 2(1), 15-28. 
Pajo, K., \& Wallace, C. (2007, August 10). Barriers To The Uptake Of Web-based Technology By University Teachers. International Journal of E-Learning \& Distance Education. Retrieved from http://ijede.ca/index.php/jde/article/view/171/127

Pickering, G., \& Gunashekar, P. (2015). Innovation in English Language Teacher Education. Innovation in English Language Teacher Education. Retrieved from http://www.britishcouncil.in/sites/britishcouncil.in2/files/tec14_papers_final_o nline.pdf\#page $=275$

Rienties, B., Brouwer, N., \& Lygo-Baker, S. (2013). The effects of online professional development on teachers' beliefs and intentions towards learning facilitation and technology. Teaching and Teacher Education, 29, 122-131. https://doi.org/10.1016/j.tate.2012.09.002

Rozgiene, I. Medvedeva, O. Strakova, Z. (2008). Integrating ICT into Language Learning and Teaching: Guide for Tutors. (Z. S. Inga Rozgiene, Olga Medvedeva, Ed.). ODLAC: Johannes Kepler Universitat Linz, Altenberger Strabe 69, 4040 Linz.

Sector, T., \& Council, S. (2007). Inclusive learning approaches for literacy , language, numeracy and ICT For use by awarding institutions, teacher educators, employers, teachers and Companion guide to the minimum core November 2007. Lifelong Learning, (November).

Son, J.-B. (2011). Online Tools for Language Teaching. Retrieved February 3, 2016, from http://www.tesl-ej.org/wordpress/issues/volume15/ej57/ej57int/

Szecsy, C. E. M. (2015). Technology in Language Teaching and Learning. In J. M. Gonzales (Ed.), Encyclopedia of Bilingual Education (pp. 822-826). Thousand Oaks: SAGE Publications. https://doi.org/http://dx.doi.org/10.4135/9781412963985.n313

Teacher Technology Competency Commitee. (1998). Teacher Technology Competencies. Teacher Technology Competency Committee. Retrieved from http://www.edb.utexas.edu/education/assets/files/ltc/about/TTCompetencies.pd $\mathrm{f}$

Tomlinson, B. (2011). Materials development in language teaching (Second Edi). Cambridge, UK: Cambridge University Press.

Unesco. (2008). ICT Competency Standards for Teachers: Competency Standards Modules. The United Nations Educational, Scientific and Cultural Organization. Retrieved from http://cst.unesco-ci.org/sites/projects/cst/The Standards/ICT-CST-Competency Standards Modules.pdf

Unesco. (2011). Unesco ICT competency framework for teachers. France.

Voss, B. D. (2013). Massive Open Online Courses (MOOCs): A Primer for University and College Board Members. Retrieved from http://agb.org/reports/2013/massive-open-online-courses-moocs-primeruniversity-and-college-board-members

Yusuf, M. O., \& Balogun, M. R. (2011). Student-Teachers ' Competence and Attitude towards Information and Communication Technology: A Case Study in a Nigerian University. Contemporary Educational Technology, 2(1), 18-36.

Zhang, D., Zhao, S., \& Li, L. (2014). Teachers' Perceptions and Use of Information 
Being an E-Teacher: Preparing the ESL Teacher

and Communication Technologies (ICTs) in Chinese Language Education. In S. Li \& P. Swanson (Eds.), Engaging Language Learners through Technology Integration: Theory, Applications, and Outcomes (pp. 237-256). IGI global; Harshey, PA. https://doi.org/10.4018/978-1-4666-6174-5.ch011 